\title{
FAKTOR-FAKTOR YANG MEMPENGARUHI PENGAMBILAN KEPUTUSAN INVESTASI INVESTOR INDIVIDU DI KOTA MATARAM
}

\author{
G. A. Sri Oktaryani' ${ }^{1}$, Siti Sofiyah Abdul Manan² \\ 1Fakultas Ekonomi dan Bisnis Unram. E-mail: oktaryani@gmail.com
}

\begin{abstract}
ARTICLE INFO
Keywords :

investment decision, individual investor, financial literacy, advice, future needs, time duration, risk and return

Kata Kunci :

Keputusan investasi, investor individu, literasi finansial, saran, kebutuhan masa depan, jangka waktu, risiko dan return

\section{How to cite :}

Oktaryani, G. A. Sri., Abdul Manan, Siti Sofiyah., (2020). Faktor-faktor Yang Mempengaruhi Pengambilan Keputusan Investasi Investor Individu Di Kota Mataram.9 (4), JMM UNRAM, 341-352
\end{abstract}

DOI :

http://dx.doi.org/10.29303/jmm.v9i4.584

$\begin{array}{ll}\text { Dikumpulkan } & : 07 \text { Oktober } 2020 \\ \text { Direvisi } & : 20 \text { Oktober } 2020 \\ \text { Dipublikasi } & : \text { :05 November } 2020\end{array}$

\begin{abstract}
This study is aimed to identify the factors that influence investment decision making by individual investors in the city of Mataram. Due to the importance of investment decision for individual investor, various factors surely are taken into consideration before deciding into some kind of invesment transaction. Survey is conducted on 100 people from different age groups and professions in the city of Mataram. Most of the respondents choose to invest in asset such as real estate and gold, only a few of them choose market securities as investment. The results of the factor analysis show that there are five factors which affect investment decisions of individual investors in the cityMataram, namely financial literacy, advice and protection, future needs, time duration of investment, and risk and return.

Penelitian ini bertujuan untuk mengidentifikasi faktor-faktor yang mempengaruhi pengambilan keputusan investasi oleh investor individu yang ada di wilayah kota mataram. Mengingat pentingnya keputusan investasi bagi seorang investor, tentunya individu tersebut memiliki berbagai faktor yang dijadikan sebagai bahan pertimbangan sebelum memutuskan untuk bertransaksi dalam sebuah instrumen investasi. Survey yang dilakukan terhadap 100 orang yang berasal dari beberapa kelompok usia dan profesi yang berbeda yang ada di kota mataram. Dari hasil analisis faktor diperoleh lima faktor yang mempengaruhi keputusan investasi bagi investor individu di
\end{abstract}




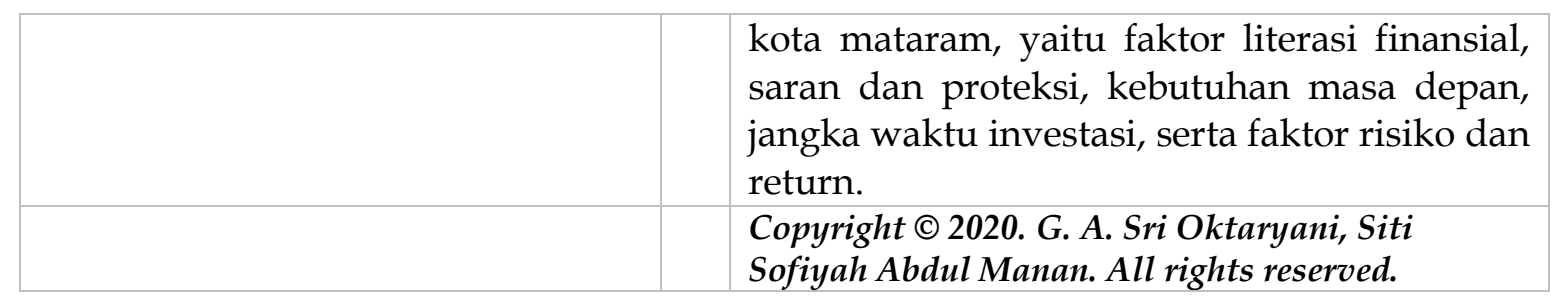

\section{PENDAHULUAN}

Di saat seseorang memutuskan untuk berinvestasi tentunya berharap bahwa investasi tersebut akan menghasilkan keuntungan di masa yang akan datang. Namun mengingat bahwa masa depan penuh dengan ketidakpastian, hasil yang didapat bisa saja menyimpang dari yang diharapkan. Dalam manajemen investasi, kemungkinan penyimpangan dari harapan menggambarkan risiko investasi. Keputusan investasi bagi investor individu merupakan sebuah keputusan yang penting karena hal tersebut akan berimbas pada kehidupan ekonominya di masa depan. Sehingga penetapan tujuan investasi merupakan langkah awal yang penting untuk dilakukan oleh seorang investor. Selanjutnya, investor juga perlu mengenali mekanisme investasi dan lingkungan sasaran investasi seperti mekanisme jual-beli, regulasi yang terkait dengan investasi yang hendak dipilih maupun pajak yang harus dibayarkan atas kepemilikan investasi.

Pemilihan investasi tentunya dapat berbeda antara satu investor dengan investor lainnya dan di masa sekarang pilihan investasi tentunya lebih beragam dibandingkan masa lalu. Investor dapat menanamkan investasinya dalam sektor properti (real estate), emas, deposito ataupun dalam bentuk sekuritas seperti saham dan obligasi. Investor individu yang memilih untuk menyimpan dana dalam bentuk deposito tentunya tidak bisa return yang tinggi dalam situasi tingkat suku bunga perbankan yang relatif stabil dan rendah, namun risiko investasinya juga terbilang rendah. Sebaliknya investasi pada saham dan obligasi dapat memberikan tingkat pengembalian yang lebih besar namun risiko atas investasi jenis ini juga relatif lebih tinggi. Sehingga sebelum mengambil keputusan investasi, investor seharusnya memiliki pengetahuan yang cukup berkaitan dengan jenis investasi yang hendak dipilih.

Pengambilan keputusan terjadi sebagai reaksi atas suatu masalah yang sedang dihadapi. Adanya perbedaan antara situasi yang sesungguhnya dengan situasi yang diinginkan, yang membuat individu untuk mempertimbangkan alternatif-alternatif tindakan yang harus dilakukan untuk mengatasi atau menyelesaikan masalah tersebut (Wulandari \& Iramani, 2014). Namun dalam teori keuangan konvensional perilaku keuangan dari sudut psikologi kurang diperhatikan, padahal kondisi psikologis seperti sendiri kepercayaan diri yang berlebihan dan emosi merupakan dasar dari keinginan dan motivasi manusia sekaligus sumber kekeliruan manusia. Kesalahan (error) dan bias ini nyatanya melanda seluruh aspek keuangan dan mempengaruhi semua pelaku pasar (Hidayati, 2018).

Pengambilan keputusan umumnya dipengaruhi oleh persepsi seseorang. Persepsi adalah suatu proses yang ditempuh individu-individu untuk mengorganisasikan dan menafsirkan kesan indera mereka agar memberi makna kepada lingkungan. Namun apa yang merupakan persepsi seseorang dapat berbeda dari kenyataan yang objektif. Karena perilaku orang didasarkan pada persepsi mereka akan realitas, dan bukan pada realitas itu sendiri sehingga keputusan tersebut sering didasarkan pada penilaianindividu yang jauh dari asumsi yang rasional(Robbins \& Judge, 2008). 
Berdasarkan latar belakang yang dipaparkan di atas, penelitian ini bertujuan untuk mengidentifikasi faktor-faktor yang mempengaruhi pengambilan keputusan investasi yang difokuskan pada investor individu di Kota Mataram.

\section{KAJIAN TEORITIS}

Behavioral finance atau keuangan keperilakuan mempelajari tentang pengaruh dari perilaku sosial dan fenomena psikologis terhadap keputusan keuangan yang diambil. Tujuan dari behavioral finance adalah memahami dan memprediksi implikasiimplikasi sistematis pasar keuangan dari sudut pandang psikologis (Ricciardi \& Simon, 2000). Teori portofolio modern yang didasarkan pada paradigma neoklasik, umumnya mengasumsikan bahwa investor berperilaku rasional, dimana dalam setiap pengambilan keputusan berdasarkan pertimbangan-pertimbangan yang logis dalam memilih investasi. Namunbeberapa penelitian menunjukkan bahwa dalam setiap proses pengambilan keputusan investasi, baik kelompok maupun individu ternyata melibatkan faktor psikologis dalam proses pengambilan keputusan investasi. Suatu ketika, rasionalitas mungkin lebih mendominasi reaksi seseorang terhadap suatu informasi, tetapi pada saat lain mungkin sebaliknya.

Penelitian eksperimental yang dilakukan oleh Fishchhoff et al. (1977) seperti dikutip dalam Hidayati (2008), menunjukkan bahwa kecenderungan munculnyakepercayaan diri yang berlebihan adalah hal yang umum dan biasa terjadi serta melekat dalam diri setiap orang. Contohnya seorang investor yang baru melakukan dua-tiga kali transaksi tetapi sudah merasa cukup cerdik dalam membuat berbagai keputusan investasi. Teori ini kemudian dikenal sebagai overconfidencetheory.Menurut Wendy (2012) dalam Asri (2013), perilaku overconfidence mempunyai implikasi terhadap perilaku investor dalam mengambil keputusan. Perilaku ini membuat seseorang terlalu optimis akan keberhasilannya mengendalikan segala permasalahan investasi sehingga ia menjadi overestimate terhadap hasil investasi tersebut dan menyebabkan kesalahan estimasi terhadap target investasi potensial. Seorang investor bisa saja sebenarnya tidak begitu mengerti tentang target investasi, atau hanya sekedar mengetahui tetapi tidak melakukan analisis yang layak atas data statistik karena terlalu percayapada kinerja suatu target investasi sehingga cenderung meremehkan risikonya.

Teori lainnya adalah financial cognitive dissonance dikembangkan oleh Festinger (Hidayati, 2018), yang menyatakan bahwa manusia merasakan tekanan internal dan keraguan atau ketakutan manakala dihadapkan pada benturan atau perbedaan keyakinan. Contohnya saat seseorang merubah gaya atau keyakinan investasi untuk mendukung keputusannya. Misalnya, investor yang biasanya menggunakan analisis fundamental dengan menggunakan rasio-rasio keuangan dalam mengevaluasi perusahaan, merubah keyakinannya dan beralih pada analisis tehnikal yang berpatokan pada informasi historis pergerakan harga saham.

Statman (1995) dalam Asri (2013) melakukan penelitian yang memfokuskan pada gejala psikologis yang disebut dengan fear of regret, yang pada akhirnya menyebabkan investor ragu-ragu dan bertindak tidak rasional. Seseorang cenderung untuk lebih berhati-hati (sebagai cerminan besarnya fear of regret) apabila keputusan yang dibuatnya akan berakibat terhadap keluarganya. Sebaliknya ia cenderung lebih berani mengambil keputusan yang hanya akan berakibat pada dirinya sendiri.Teori ini menyatakan bahwa individu melakukan evaluasi reaksi harapan pada suatu kejadian atau situasi di masa depan. Misalnya jika seorang investor pernah mengalami kerugian 
atas investasinya pada saham " $\mathrm{X}$ ", maka yang bersangkutan melakukan perbaikan analisis agar di masa datang tidak mengalami hal yang sama. Teori ini dikenal sebagai theory of regret(Hidayati, 2018).

Kahneman dan Tverskysebagai penggagas prospect theorymengungkapkan bahwa manusia tidak selalu berperilaku secara rasional dengan anggapan bahwa ada bias yang melekat dan terus ada yang dimotivasi oleh faktor-faktor psikologis yang mempengaruhi pilihan orang dibawah kondisi ketidakpastian. Teori ini mempertimbangkan preferensi sebagai suatu fungsi pilihan keputusan dan berasumsi bahwa pilihan-pilihan tersebut tidak selalu tepat dengan probabilitas. Investor sering mempertahankan investasi yang mengalami kerugian dengan harapan akan terjadi pemulihan kelak di kemudian hari (Asri, 2013; Hidayati, 2018).

Shiller (1995) dalam Asri (2013) mengidentifikasi adanya perilaku kelompok yang secara bersama-sama melakukan suatu tindakan dengan saling meniru satu sama lain, padahal mungkin mereka sama-sama tidak tahu apa yang sesungguhnya mereka lakukan. Perilaku ini bersifat universal, artinya dapat dialami oleh siapa saja meskipun ia berpendidikan tinggi, berpengalaman dalam investasi, laki-laki atau perempuan, tua atau muda, serta investor besar ataupun kecil. Teori ini dikenal sebagai herding theory.Terkait dengan fear of regret menyebabkan investor yang cenderung mengikuti arus, dengan pertimbangan seandainya investasi yang dilakukan tidak menguntungkan, maka hal tersebut tidak dialami oleh dirinya saja. Dalam suatu komunitas atau kelompok yang melakukan hal yang sama bisa saja ada seseorang yang dinilai pantas untuk menjadi pemimpin. Orang tersebut cenderung didengar, diperhatikan dan diikuti oleh yang lainnya. Kalau ia membeli, semua akan membeli. Kalau ia menjual maka semua akan menjual.

Elster (1998), Hermalin dan Isen (2000) dalam Asri (2013) juga menunjukkan bahwa emosi seseorang berpengaruh dalam proses pengambilan keputusan. Fenomena ini terjadi baik pada pria ataupun wanita, tua atau muda, terpelajar ataupun tidak. Loewenstein et al. (2001) dalam Asri (2013) menemukan bahwa reaksi emosional terhadap situasi berisiko seringkali berbeda dengan reaksi yang seharusnya menurut perkiraan kognitif terhadap risiko tersebut.

Kabra, Mishra \& Dash (2010) yang melakukan penelitian di India mengungkapkan 6 faktor yang mendasari pengambilan keputusan investasi, yaitu: security, opini, awareness, hedging, benefit, dan duration. Diungkapkan juga bahwa mayoritas investor menggunakan informasi dari sumber tertentu dan memiliki suatu kelompok (reference group) dalam mengambil keputusan. Meskipun para investor ini terjebak dalam ilusi kognitif seperti overconfidence, namun mereka juga mempertimbangkan berbagai faktor dan informasi sebelum memutuskan untuk bertransaksi membeli suatu instrumen investasi.

Sahi, Arora, \& Dhameja(2013)meneliti keyakinan dan sikap investor individu di kota Delhi, India berkaitan dengan pengambilan keputusan investasi. Hasil penelitiannya mengungkapkan bahwa motif psikologis, strategi pemrosesan informasidan prinsip pengorganisasian perseptual serta pengaruh afektif dan emosi mempengaruhi proses pengambilan keputusan bagi investor individu. Motif psikologis mencakup: kecenderungan untuk mengkonfirmasi informasi, cenderung bermain aman, cenderung berinvestasi pada instrumen yang familiar, cenderung bergantung pada pendapat keluarga dan teman, cenderung berkonsultasi atau tidak berkonsultasi pada ahli keuangan, cenderung percaya diri terhadap kemampuan diri dan bergantung pada keahlian diri sendiri. Di sisi lain, pengaruh afektif dan emosi mencakup: perasaan takut mengalami kerugian, perasaan menyesal, merasa seharusnya bisa membuat keputusan 
yang lebih baik di masa lalu, menghindari ketidakpastian, dan tanggung jawab sosial. Sedangkan strategi pemrosesan informasidan prinsip pengorganisasian perseptual mencakup: kecenderungan bergantung pada referensi dan informasi yang mudah diperoleh, cenderung melihat perkiraan hasil, cenderung konsumtif, melakukan investasi yang berbeda untuk pendapatan dari sumber yang berbeda, serta cenderung mengikuti tren.

Penelitian lainya tentang faktor-faktor yang mempengaruhi perilaku investor individual dilakukan oleh Nagy \& Obenberger(2015), namun penelitian ini memfokuskan pada investor individu yang berinvestasi pada saham. Hasil penelitian menunjukkan terdapat 7 faktor yang mempengaruhi proses pemilihan saham yang dibeli, yaitu: informasi yang netral, informasi akuntansi, image perusahaan, faktor klasik, relevansi sosial, rekomendasi konsultan (broker, teman atau rekan kerja), serta kebutuhan keuangan individu.

\section{METODE PENELITIAN}

\subsection{Jenis Penelitian}

Penelitian ini dilakukan untuk mengetahui faktor-faktor apa saja yang mempengaruhi pengambilan keputusan investasi bagi investor individu. Sehingga dapat dikatakan bahwa penelitian ini merupakan studi explorasi yang bertujuan untuk menggali variabel-variabel atau faktor-faktor yang terdapat pada suatu fenomena (Indriantoro \& Supomo, 2009).

\subsection{Populasi dan Sampel}

Populasi dalam penelitian ini adalah masyarakat Kota Mataram yang sudah pernah melakukan investasi baik dalam bentuk aset riil ataupun aset keuangan. Sampel dalam penelitian ini dipilih dengan metode non probability sampling dengan kriteria umur di atas 20 tahun dengan pendekatan convenience sampling. Jumlah sampel ditentukan sebanyak 100 responden dengan mempertimbangkan pendapat Roscoe (1975) yang dikutip dari Sekaran (2006) yang memberikan acuan umum untuk menentukan ukuran sampel yakni lebih dari 30 sampai dengan 500.

\subsection{Metode Pengumpulan Data}

Metode pengumpulan data menggunakan kuesioner yang disebar pada responden sesuai kriteria di Kota Mataram. Selanjutnya responden diminta untuk mengisi kuesioner yang diberikan.

\subsection{Instrumen Survey}

Survey dilakukan dengan menyebarkan kuisioner pada 100 responden. Halaman awal kuisioner terdiri atas pertanyaan yang menyangkut karakteristik responden seperti gender, usia, profesi,dan penghasilan. Sedangkan bagian utama dari kuisioner berisi pernyataan-pernyataan yang diukur dengan skala likert (1 5) dengan kriteria sebagai berikut:

- sangat tidak penting (skor 1)

- tidak penting (skor 2)

- kurang penting (skor 3)

- penting (skor 4)

- sangat penting (skor 5)

Pernyataan-pernyataan dalam kuisioner dikembangkan dengan merujuk pada penelitianSahi, Arora, \& Dhameja(2013) sertaKabra, Mishra \& Dash (2010) karena variabel-variabel yang ada dalam kedua penelitian tersebut telah mengarah 
pada teori-teori perilaku dalam keuangan seperti overconfidence theory, theory of regretdan herding theory.

\subsection{Prosedur Penelitian}

Studi awal lapangan dilakukan untuk memahami kondisi lapangan dan karakteristik responden serta menggali persepsi investor individu terkait dengan pengambilan keputusan investasi dengan cara mewawancarai sejumlah orang yang aktif melakukan investasi. Selanjutnya dikembangkan serangkaian pertanyaan atau pernyataan yang digunakan untuk mendapatkan data dari responden terkait dengan preferensi investor individu terhadap investasi. Kuisioner diberikan pada responden sambil melakukan wawancara untuk memastikan bahwa responden mengerti dengan pertanyaan dan pernyataan yang ada dalam kuisioner. Selanjutnya dilakukan ujireliabilitas. Reliabilitas adalah alat untuk mengukur suatu kuisioner yang merupakan indikator dari peubah atau konstruk. Suatu kuisioner dikatakan reliabel atau handal jika jawaban seseorang terhadap pernyataan adalah konsisten atau stabil dari waktu ke waktu. Reliabilitas suatu test merujuk pada derajat stabilitas, konsistensi, daya prediksi, dan akurasi. Pengukuran yang memiliki reliabilitas yang tinggi adalah pengukuran yang dapat menghasilkan data yang reliabel.

\subsection{Alat Analisis Data}

Data dianalisis dengan menggunakan Statistik Deskriptif diperlukan untuk mendapatkan gambaran umum tentang karakteritik dari responden seperti gender, usia, penghasilan dan profesi. Selanjutnya dilakukan analisis faktor mendefinisikan struktur suatu data matrik dan menganalisis struktur korelasi antar sejumlah besar variabel dengan cara mendifinisikan satu set kesamaan variabel dan sering disebut sebagai faktor. Dengan analisis faktor, peneliti mengidentifikasi variabel-variabel yang sekiranya dipertimbangkan dalam keputusan investasi dan seberapa jauh setiap variabel dapat dijelaskan oleh setiap dimensi. Begitu dimensi dan penjelasan setiap variabel diketahui, maka dua tujuan utama analisis faktor dapat dilakukan yaitu data summarization dan data reduction(Ghozali, 2012).

\section{HASIL DAN PEMBAHASAN}

\subsection{Hasil}

\subsubsection{Karakteristik Responden}

Dari 100 responden yang ditemui dalam survei penelitian ini, 56 persen terdiri dari laki-laki dan 44 persen terdiri dari perempuan. Dari segi usia, responden dalam penelitian ini didominasi oleh individu yang berasal dari kelompok usia 41 - 60 tahun sebesar 43 persen, disusul oleh responden yang berusia 30 - 40 tahun sebanyak 29 persen dan responden yang berusia 20 - 29 tahun sebanyak 27 persen. Sedangkan responden yang berusia di atas 60 tahun hanya 1 persen.

Dari sisi penghasilan, hampir separuh responden (47 persen) memiliki penghasilan per bulan yang berkisar antara Rp 2.000.000,- sampai dengan Rp $5.000 .000,-$. Selain itu terdapat 27 persen responden yang berpenghasilan $\mathrm{Rp}$ 5.000 .000 - Rp 10.000.000 dan 22 persen responden berpenghasilan di bawah $\mathrm{Rp}$ $2.000 .000,-$. Sementara itu hanya 5 persen responden yang memiliki penghasilan di atas Rp 10.000.000. 
Gambar 1. Jenis Investasi

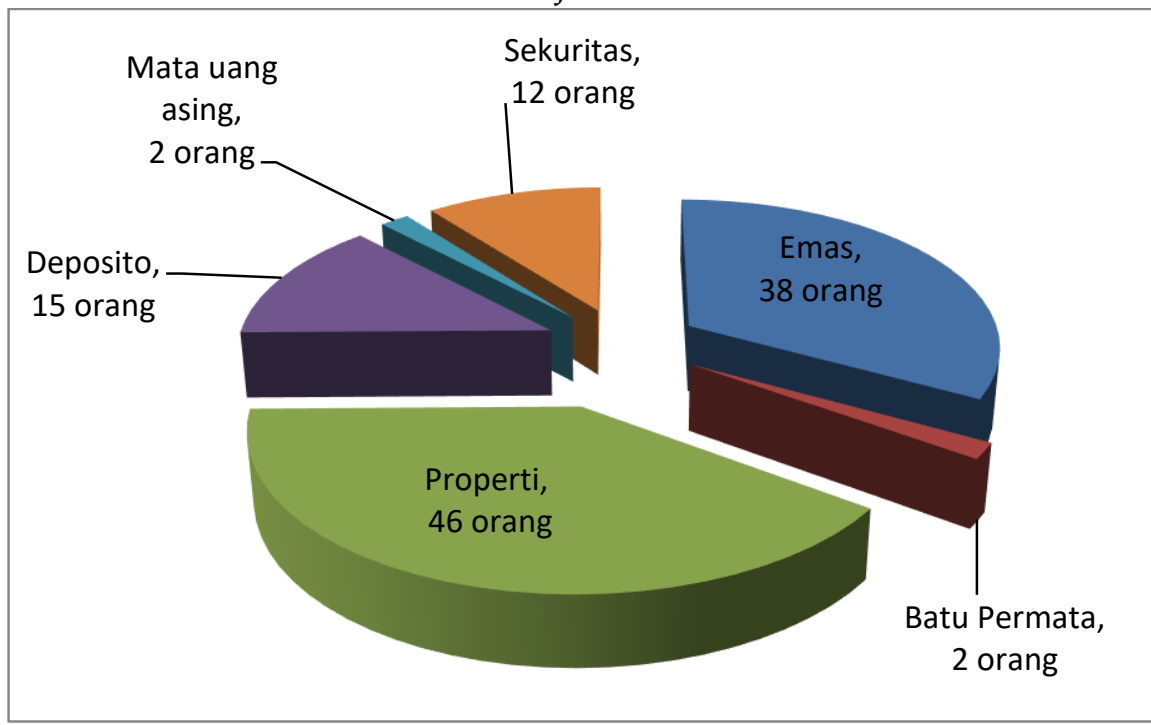

Sumber: data primer diolah

Dilihat dari jenis investasi, terdapat 46 responden yang telah berinvestasi pada investasi berupa properti. Sehingga bisa dikatakan bahwa investasi berupa properti merupakan jenis investasi yang paling diminati oleh para responden. Investasi kedua yang juga banyak dimiliki oleh responden adalah emas. Sedangkan sisanya berinvestasi dalam bentuk deposito, sekuritas, mata uang asing dan batu permata. Dari hasil survey terhadap 100 responden diketahui ada beberapa orang yang pernah berinvestasi pada lebih dari satu instrumen investasi. Diantaranya terdapat 10 orang yang pernah memiliki 2 jenis investasi dan ada 3 orang yang pernah berinvestasi pada lebih dari 2 instrumen investasi. Sedangkan profesi responden dapat dilihat dalam dan tabel 1.

Tabel 1. Profesi Responden

\begin{tabular}{|l|c|}
\hline \multicolumn{1}{|c|}{ Profesi } & Persentase \\
\hline wirausaha & $39 \%$ \\
Karyawan swasta & $22 \%$ \\
PNS & $10 \%$ \\
TNI/Polri & $8 \%$ \\
Guru & $6 \%$ \\
Dosen & $5 \%$ \\
Pegawai honor & $3 \%$ \\
Pensiunan & $3 \%$ \\
Mahasiswa & $2 \%$ \\
Pegawai BUMN & $1 \%$ \\
Pemandu wisata & $1 \%$ \\
\hline Total & $100 \%$ \\
\hline
\end{tabular}

\subsubsection{Uji Reliabilitas}

Sumber: data primer diolah

Uji reliabilitas ini dilakukan pada seluruh pernyataan dalam kuisioner penelitian. Hasil uji reliabilitas menunjukkan nilai cronbach's alpha sebesar 0,753 
seperti tertera pada tabel 2. Ini berarti kuisioner penelitian dapat dikatakan reliabel dengan derajat stabilitas, konsistensi, daya prediksi, dan akurasi yang tinggi karena nilai cronbach's alpha berada di rentang 0,7 sampai dengan 0,9. Pengukuran yang memiliki reliabilitas yang tinggi nantinya dapat menghasilkan data yang reliabel.

\section{Tabel 2. Hasil Uji Reliabilitas}

\begin{tabular}{|c|c|}
\hline $\begin{array}{c}\text { Cronbach's } \\
\text { Alpha }\end{array}$ & N of Items \\
\hline .753 & 16 \\
\hline \multicolumn{2}{|c|}{ Sumber: data primer diolah }
\end{tabular}

\subsubsection{Identifikasi Faktor}

Untuk menentukan dapat atau tidaknya analisis faktor dilakukan adalah dengan melakukan uji KMO (Kaiser-Meyer-Olkin) danBartlett's test of sphecity. Uji ini dilakukan terhadap 16 pernyataan yang menggambarkan persepsi individu dari responden. Diperoleh nilai KMO (Kaiser-Meyer-Olkin) sebesar 0,670 dan nilai signifikansi Bartlett's test of sphecity sebesar 0,00. Berdasarkan nilai KMO yang melebihi 0,50 dan nilai Bartlett's test of sphecity yang signifikan berarti bahwa data yang ada dapat dianalisis dengan menggunakan analisis faktor.

Tabel 3. KMO and Bartlett's Test

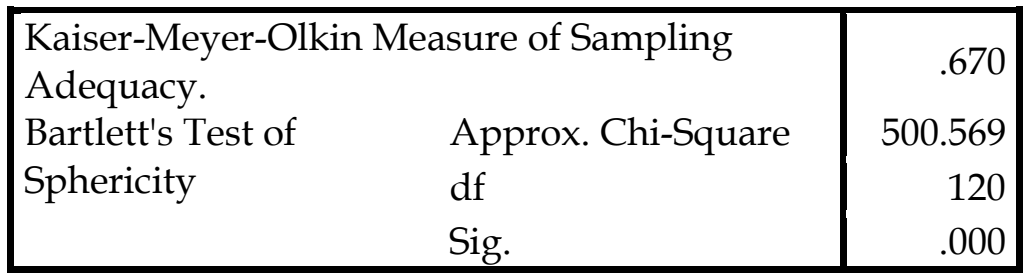

Sumber: data primer diolah

Langkah selanjutnya adalah menentukan jumlah faktor dengan melihat eigen value dan variance dari masing-masing komponen. Hanya yang memiliki eigen value> 1 yang dianggap sebagai faktor. Selain itu, untuk membantu interpretasi faktor dilakukan rotasi faktor untuk memperjelas variabel yang masuk ke dalam kelompok faktor tertentu. Metode rotasi orthogonal dengan varimax digunakan karena tujuannya adalah untuk mengurangi dan mengerucutkan variabel(Ghozali, 2012).

Tabel 4. Faktor Persepsi dan Persentase Variance Explained

\begin{tabular}{|l|c|r|c|}
\hline \multicolumn{1}{|c|}{ FAKTOR } & Eigen Value & $\%$ Variance & $\begin{array}{c}\% \\
\text { Cumulative } \\
\text { Variance }\end{array}$ \\
\hline Literasi finansial & 3,909 & 24,431 & 24,431 \\
\hline Saran dan Proteksi & 2,111 & 13,191 & 37,622 \\
\hline Kebutuhan masa depan & 1,548 & 9,676 & 47,297 \\
\hline Jangka waktu investasi & 1,449 & 9,057 & 56,355 \\
\hline Risiko dan return & 1,141 & 7,133 & 63,487 \\
\hline
\end{tabular}


Sumber: data primer diolah

Berdasarkan tabel 4 diketahui bahwa terdapat 5 komponen yang memiliki eigen value $>1$ yang selanjutnya disebut sebagai faktor. Kelima faktor tersebut secara total mampu menjelaskan $63,49 \%$ dari total variance dan sisanya dijelaskan oleh faktor lain yang belum diketahui. Faktor literasi finansial mampu menjelaskan $24,43 \%$ variasi dan faktor saran dan proteksi mampu menjelaskan $13,19 \%$. Selanjutnya faktor kebutuhan masa depan mampu menjelaskan 9,68\% variasi dan faktor jangka waktu investasi mampu menjelaskan 9,06\%. Sedangkan faktor risiko dan return hanya mampu menjelaskan 7,13\% variasi.

Setelah dilakukan rotasi orthogonal dengan varimax terdapat 1 variabel harus dieliminasi karena nilai factor loading yang lebih rendah dari 0,5. Pengelompokkan variabel (pernyataan dalam kuisioner) ke dalam lima faktor dilakukan dengan melihat nilai factor loading dari rotated component matrix.

\section{A. Literasi Finansial}

Tabel 5 menunjukkan bahwa Faktor literasi finansial disusun atas 3 (tiga) variabel. Jika dicermati, variabel-variabel yang termasuk ke dalam faktor ini mengarah pada kemampuan dan keterampilan individu dalam menilai instrumen investasi seperti pentingnya memiliki kemampuan untuk menganalisis likuiditas investasi dan pengetahuan perencanaan keuangan untuk dapat mengambil keputusan investasi. Sebagian besar responden juga merasa penting untuk dapat memahami peningkatan nilai investasi, sehingga Faktor ini disebut sebagai faktor literasi finansial.

Tabel 5. Literasi Finansial

\begin{tabular}{|l|c|}
\hline \multicolumn{1}{|c|}{ Variabel } & Factor Loading \\
\hline Kemampuan menganalisis likuiditas investasi & 0,865 \\
\hline Memahami peningkatan investasi dalam nilai & 0,831 \\
\hline Pengetahuan perencanaan keuangan & 0,535 \\
\hline
\end{tabular}

Sumber: data primer diolah

\section{B. Saran dan Proteksi}

Tabel 6 menunjukkan variabel-variabel yang termasuk ke dalam faktor saran dan proteksi. Faktor ini disusun atas variabel sarandari teman sebaya, saran dari rekan kerja, saran dari keluarga yang mengarah pada opini atau saran yang dipertimbangkan dalam proses pengambilan keputusan. Variabel lainnya adalah kepentingan daruratyang mencerminkan tujuan investasi untuk mendapat perlindungan atau proteksi jika investor dihadapkan pada situasi yang mendesak secara finansial, sehingga faktor ini disebut sebagai faktor saran dan proteksi.

Tabel 6. Saran dan Proteksi

\begin{tabular}{|l|c|}
\hline \multicolumn{1}{|c|}{ Variabel } & Factor Loading \\
\hline Saran dari teman sebaya & 0,825 \\
\hline Saran dari rekan kerja & 0,791 \\
\hline Saran dari keluarga & 0,729 \\
\hline Kepentingan darurat & 0,502 \\
\hline \multicolumn{2}{|c|}{ Sumber: data primer diolah }
\end{tabular}




\section{Kebutuhan Masa Depan}

Berdasarkan tabel 7 terlihat bahwa empat variabel yang mengelompok dalam faktor ini mengarah pada harapan investor di masa depan dan investasi yang ditujukan untuk jangka panjang. Sehingga faktor ini diberi label faktor kebutuhan masa depan.

Tabel 7. Kebutuhan Masa Depan

\begin{tabular}{|l|c|}
\hline \multicolumn{1}{|c|}{ Variabel } & Factor Loading \\
\hline Kebutuhan keluarga di masa depan & 0,706 \\
\hline Jaminan di hari tua & 0,682 \\
\hline Kemudahan menjual kembali & 0,670 \\
\hline $\begin{array}{l}\text { Minat berinvestasi untuk jangka waktu lebih } \\
\text { dari 5 tahun }\end{array}$ & 0,653 \\
\hline
\end{tabular}

Sumber: data primer diolah

\section{Jangka Waktu Investasi}

Tabel 8 menunjukkan bahwa faktor keempat dalam hasil analisis faktor terdiri dari minat berinvestasi untuk jangka waktu kurang dari 1 tahun dan jangka waktu antara 1 - 2 tahun yang mana semua variabel tersebut merujuk pada jangka waktu investasi. Sehingga faktor ini disebut sebagai disebut sebagai Faktor jangka waktu investasi.

Tabel 8. Jangka Waktu Investasi

\begin{tabular}{|l|c|}
\hline \multicolumn{1}{|c|}{ Variabel } & Factor Loading \\
\hline $\begin{array}{l}\text { Minat berinvestasi untuk jangka waktu kurang dari 1 } \\
\text { tahun }\end{array}$ & 0,809 \\
\hline Minat berinvestasi untuk jangka waktu 1- 2 tahun & 0,793 \\
\hline
\end{tabular}

Sumber: data primer diolah

\section{E. Risiko dan Return}

Dari tabel 9 di bawah terdapat dua variabel yang menyusun faktor risiko dan return. Disebut sebagai faktor risiko dan return karena variabel pertama dalam faktor ini adalah variabel keamanan dan risiko yang menjadi bahan pertimbangan bagi investor individu sebelum mengambil keputusan investasi sedangkan variabel kedua berinvestasi demi peningkatan nilai investasi, yang mengarah pada return atau pengembalian investasi yang diharapkan oleh responden (investor individu).

Tabel 9. Risiko dan Return

\begin{tabular}{|l|c|}
\hline \multicolumn{1}{|c|}{ Variabel } & Factor Loading \\
\hline Keamanan dan risiko & 0,743 \\
\hline Berinvestasi demi peningkatan nilai investasi & 0,695 \\
\hline
\end{tabular}

Sumber: data primer diolah

\subsection{PEMBAHASAN}

Jika dilihat dari karakteristik responden, sebagian besar responden berada pada rentang usia 41 - 60 tahun. Dimana dalam usia ini biasanya seseorang mempertimbangkan lebih banyak hal sebelum mengambil keputusan. Selain itu 
39 persen responden berprofesi sebagai sebagai wirausahawan dan 22 persen sebagai karyawan swasta. Faktor pertama yang dianggap penting oleh responden adalah faktor literasi finansial. Dalam hal ini literasi finansial tentunya menjadi penting bagi wirausahawan, tidak saja bagi keberlanjutan usahanya. Selain itu literasi finansial yang tinggi dapat menghindarkan seseorang pada kesulitan keuangan, sehingga faktor ini juga menjadi penting bagi investor individu lainnya.

Faktor kedua yang dianggap penting adalah Saran dan Proteksi. Saran atau informasi dari teman, rekan kerja ataupun keluarga dapat menjadi salah satu sumber dari pengetahuan pegelolaan keuangan. Selain itu proteksi untuk kepentingan darurat seperti biaya kesehatan jika tiba-tiba sakit atau dana darurat untuk kepentingan bisnis juga merupakan hal pertimbangan penting dalam pengambilan keputusan investasi.

Faktor ketiga yaitu kebutuhan masa depan. Jika dihubungkan dengan usia responden yang Sebagian besar berasal dari kelompok usia 41 - 60 tahun dan 30 40 tahun maka pertimbangan kebutuhan masa depan ini karena sudah mendekati masa pensiun, terutama bagi mereka yang bekerja sebagai karyawan baik itu swasta maupun PNS. Dimana pada usia ini umumnya telah memikirkan jaminan di hari tua dan kebutuhan keluarga di masa depan setelah mereka tidak produktif lagi dalam bekerja.

Faktor keempat yaitu jangka waktu, dimana lebih banyak orang yang tertarik untuk melakukan investasi dalam jangka pendek. Jika dihubungkan dengan karakteristik responden, jika dijumlahkan, jumlah investor yang berinvestasi pada emas, deposito dan sekuritas masih lebih banyak dibandingkan investasi pada properti.

Faktor yang kelima adalah risiko dan return. Dalam faktor ini, investor mempertimbangkan keamanan dan risiko dalam pengambilan keputusan investasi dan investasi tersebut ditujukan untuk keuntungan. Hal ini sesuai dengan Tandelilin (2010) menyebutkan beberapa alasan seseorang untuk melakukan investasi, dua diantaranya adalah risiko dan return.

\section{KESIMPULAN DAN SARAN}

\subsection{Kesimpulan}

Dari hasil penelitian diperoleh lima faktor yang mempengaruhi pengambilan keputusan investasi oleh investor individu di kota mataram, yaitu: literasi finansial, saran dan proteksi, kebutuhan masa depan, jangka waktu investasi, serta risiko dan return. Karakteristik responden menunjukkan bahwa responden terbanyak berada dalam rentang usia 41 - 60 tahun (43\%) dan usia 30 - 40 tahun $(29 \%)$, dimana seseorang pada usia ini cenderung menerapkan prinsip kehatihatian. menunjukkan bahwa jenis investasi yang paling diminati oleh responden adalah investasi dalam bentuk aset riil seperti emas dan properti.

\subsection{Saran}

Berdasarkan hasil analisis faktor, kelima faktor dalam penelitian ini secara keseluruhan hanya mampu menjelaskan $63,49 \%$ variasi, sehingga penelitian selanjutnya diharapkan dapat menggali lebih banyak informasi dari investor tentang hal-hal yang dipertimbangkan dalam pengambilan keputusan investasi. Untuk menggali informasi secara lebih luas, metode in-depth interview dapat diterapkan. 


\section{DAFTAR PUSTAKA}

Asri, M. (2013). Keuangan Keperilakuan. Yogyakarta: BPFE-UGM.

Elster, J. (1998). Emotions and Economic Theory. Journal of Economic Literature, 36(1), 4774.

Ghozali, I. (2012). Aplikasi Analisis Multivariate Dengan Program IBM SPSS 20. Semarang: Badan Penerbit - Undip.

Hidayati, S. A. (2018). Behavioural Finance dan UKM. Mataram: Sanabil.

Indriantoro, N., \& Supomo, B. (2009). Metodologi Penelitian Bisnis. Yogyakarta: BPFE.

Kabra, G., Mishra, P. K., \& Dash, M. K. (2010). Factors Influencing Investment Decision of Generations in India: An Econometric Study. International Journal of Business and Management, 1(1), 15-26.

Nagy, A., \& Obenberger, W. (2015). Factors Influencing Individual Investor Behavior. Financial Analysts Journal, 50(4), 63-68. https:/ / doi.org/10.2469/ faj.v50.n4.63

Ricciardi, V., \& Simon, H. K. (2000). What is Behavioral Finance? Business, Education and Technology Journal, 2(2), 1-9.

Sahi, S. K., Arora, A. P., \& Dhameja, N. (2013). An Exploratory Inquiry into the Psychological Biases in Financial Investment Behavior. Journal of Behavioral Finance, 14(2), 94-103. https:/ / doi.org/10.1080/15427560.2013.790387

Wulandari, D. A., \& Iramani, R. (2014). Studi Experienced Regret, Risk Tolerance, Overconfidance Dan Risk Perception Pada Pengambilan Keputusan Investasi. Journal of Business and Banking, 4(1), 55-66. https://doi.org/10.14414/jbb.v4i1.293

Sekaran, U. (2006). Metode Penelitian Bisnis. Jakarta: Salemba Empat.

Solimun, Armanu, \& Fernandes, A. C. R. (2018). Metodologi Penelitian Kuantitatif Perspektif Sistem. Malang: UB Press.

Somantri, A., \& Sambas, A. M. (2006). Aplikasi Statistika Dalam Penelitian. Bandung: Penerbit Pustaka Setia.

Tandelilin, E. (2010). Portofolio dan Investasi, Teori dan Aplikasi. Edisi Pertama. Yogyakarta: Penerbit Kanisius.

Wulandari, D. A., \& Iramani, Rr. (2014). Studi Experienced Regret, Risk Tolerance, Overconfidance Dan Risk Perception Pada Pengambilan Keputusan Investasi.Journal of Business and Banking, 4(1), 55-66. 